DOI: 10.18276/sip.2018.54/3-08

\title{
Iwona Dittmann*
}

Uniwersytet Ekonomiczny we Wrocławiu

\section{ROZKŁADY NADWYŻKOWYCH STÓP ZWROTU Z FUNDUSZY INWESTYCYJNYCH - OCENA HISTORYCZNEJ PREMII ZA RYZYKO}

\section{Streszczenie}

Celem badania była analiza kształtowania się nadwyżkowych stóp zwrotu z polskich FIO i ocena premii za ryzyko z punktu widzenia inwestora indywidualnego. Badanie przeprowadzono dla funduszy stabilnego wzrostu, zrównoważonych i akcyjnych w latach 20052017. Przyjęto dwa horyzonty inwestycyjne: 5-letni oraz 10-letni. Obliczono charakterystyki rozkładów nadwyżkowych stóp zwrotu oraz szanse uzyskania dodatniej nadwyżkowej stopy zwrotu. Stwierdzono między Innymi, iż: 1) duże zróżnicowanie nadwyżkowych stóp zwrotu nasuwa wątpliwości co do zasadności szacowania premii za ryzyko jako wartości średniej dla danego funduszu i dla całej grupy funduszy; 2) szanse na uzyskanie w przeszłości dodatniej premii za ryzyko były zróżnicowane dla poszczególnych funduszy; 3) dla 10-letniego horyzontu inwestycyjnego premia za ryzyko była ujemna.

Słowa kluczowe: fundusze inwestycyjne, finanse osobiste, nadwyżkowe stopy zwrotu, premia za ryzyko

\section{Wstęp}

Premia za ryzyko jest uważana za jedno z podstawowych zagadnień z dziedziny finansów, a oczekiwana premia za ryzyko została nazwana przez Welcha (2000, s. 501)

\footnotetext{
* Adres e-mail: iwona.dittmann@ue.wroc.pl.
} 
„być może najważniejszą liczbą w finansach”. Według tego badacza „bez dobrego oszacowania premii za ryzyko główne teorie finansów stają się bezużyteczne z praktycznego punktu widzenia" (Welch, 2000, s. 501).

Premię za ryzyko określa się jako: 1) premię z tytułu ryzyka rynkowego (market premium, equity premium) lub 2) premię za ryzyko z danego instrumentu finansowego (lub konkretnego portfela inwestycyjnego). Tę pierwszą definiuje się jako dodatkowe wynagrodzenie, którego oczekują ${ }^{1}$ (lub wymagają ${ }^{2}$ ) inwestorzy rezygnujący $\mathrm{z}$ bezpieczeństwa ulokowania kapitału w instrumenty wolne od ryzyka i podejmujący decyzję o zainwestowaniu w aktywa charakteryzujące się średnim rynkowym poziomem ryzyka (Byrka-Kita, 2013). Premia rynkowa jest jedną ze zmiennych w modelach wyceny aktywów. Natomiast premia za ryzyko z danego instrumentu finansowego wynika z podjęcia ryzyka inwestowania w konkretne aktywum (Kurek, 2011). Historyczna premia za ryzyko z danego portfela inwestycyjnego jest wielkością używaną między innymi w ocenie efektywności zarządzania funduszami inwestycyjnymi - występuje bowiem jako składowa wskaźnika Sharpe’a.

\section{Badania wyników funduszy inwestycyjnych i premii za ryzyko - przegląd literatury}

Prowadzone dotychczas badania naukowe dotyczące inwestowania w fundusze inwestycyjne skupiały się na zagadnieniach: efektywności funduszy, persystencji wyników oraz stopnia i perspektyw rozwoju rynku. Efektywność polskich funduszy inwestycyjnych w ostatnich latach badali między innymi: Żebrowska-Suchodolska (2017), Mentel, Brozyna, Szetela i Kompa (2016), Mentel i Horváthová (2016), Trzebiński (2016), Dittmann (2016a, 2016b, 2016c), Miziołek (2014, 2015), Zamojska (2012, 2015), Pietrzyk (2013, 2014a, 2014b), Jurek-Wasilewska (2014), Karpio i Żebrowska-Suchodolska (2013), Dawidowicz (2012, 2013), Jamróz (2013), Karkowska i Niewińska (2013), Perez (2012), Olbryś (2009, 2011), Kompa i Witkowska (2010). Przegląd metod stosowanych dotychczas w badaniach polskich funduszy inwestycyjnych sporządzili Miziołek i Trzebiński (2017). Badania dotyczące persystencji polskich funduszy prowadzili między innymi: Aspadarec i Majewski (2016), Czekaj i Grotowski (2014), Perez (2012b, 2011a, 2011b). Rozwój rynku funduszy był

Oczekiwana premia za ryzyko.

2 Wymagana premia za ryzyko. 
przedmiotem badań między innymi: Trzebińskiego (2013), Perez (2011c), Miziołka (2007). W badaniach wyników funduszy powszechnie używane są miary RAPM ${ }^{3}$, w szczególności zaś współczynnik Sharpe’a oparty na nadwyżkowej stopie zwrotu i współczynnik Treynora oparty na różnicowej ${ }^{5}$ stopie zwrotu. Należy podkreślić, iż prowadzone dotychczas badania można uznać za dotyczące finansów osobistych, gdyż ich wyniki stanowią użyteczną dla inwestora indywidualnego informację. Jednak w głównej mierze zostały one ukierunkowane, jak się wydaje, na badanie lub porównanie efektywności (sprawności) zarządzających funduszami.

Problematyka premii za ryzyko rynkowe jest przedmiotem licznych badań naukowych. Badania te - autorstwa zarówno naukowców zagranicznych, jak i polskich - dotyczą zwykle sposobów szacowania oczekiwanej lub wymaganej premii za ryzyko (m.in. Fernández, 2004; Damoradan, 2011; Kurek, 2009, 2011; Byrka-Kita, 2006, 2013). Największe kontrowersje metrologiczne budzi szacowanie stopy wolnej od ryzyka. W praktyce gospodarczej różne instrumenty finansowe są przyjmowane za wolne od ryzyka ${ }^{6}$, jednak żaden z nich nie spełnia całkowicie warunku niegenerowania żadnego ryzyka ${ }^{7}$. Przedmiotem badań są także determinanty premii za ryzyko (np. Damodaran, 2011) oraz znacząca różnica premii ex ante i ex post, tak zwane equity premium puzzle (np. Julliard, Ghosh, 2012; Mehra, 2001, 2003). Na ważną rolę premii za ryzyko w finansach osobistych zwraca uwagę Damodaran (2011), odnosząc się do kwestii niewystarczających oszczędności emerytalnych. Zagadnienie kształtowania się nadwyżkowej stopy zwrotu (jako różnicy między stopą zwrotu z inwestycji a stopą wolną od ryzyka) z różnych instrumentów finansowych jawi się tym samym jako ważne zagadnienie finansów osobistych.

Według najlepszej wiedzy autorki brakuje badań dotyczących premii za ryzyko prowadzonych w kontekście finansów osobistych. W celu uzupełnienia tej luki badawczej zaprojektowano badanie dotyczące oceny historycznej premii za ryzyko inwestowania w polskie fundusze inwestycyjne otwarte o charakterze udziałowym. Jako stopę „wolną od ryzyka” do obliczania nadwyżkowej stopy zwrotu z funduszy

\footnotetext{
3 Risk Adjusted Performance Measure - stopy zwrotu skorygowane o ryzyko.

4 Excess return - różnica między zwykłą stopą zwrotu a stopą zwrotu wolną od ryzyka.

5 Differential return - różnica między zwykłą stopą zwrotu a stopą zwrotu z benchmarku.

${ }_{6}$ Zazwyczaj skarbowe papiery wartościowe (w Polsce obligacje skarbowe o różnych okresach zapadalności i bony skarbowe), jednak czasem praktycy przyjmują za instrument wolny od ryzyka także depozyty bankowe. Zob. Byrka-Kita (2006).

7 Nawet przy założeniu braku ryzyka niewywiązywania się z płatności pozostaje kwestia ryzyka reinwestycji i inflacji.
} 
przyjęto stopę zwrotu z depozytów bankowych. Przy pewnych założeniach ${ }^{8}$ można uznać ją za stopę wolną od ryzyka dla inwestora indywidualnego.

Celem badania była analiza kształtowania się w przeszłości nadwyżkowych stóp zwrotu z polskich funduszy udziałowych i ocena historycznej premii za ryzyko z punktu widzenia inwestora indywidualnego. Postawiono następujące pytania badawcze:

1. Jakie było zróżnicowanie nadwyżkowych stóp zwrotu $\mathrm{z}$ danego funduszu?

2. Czy fundusze były bardzo zróżnicowane ze względu na wartości danej charakterystyki rozkładu nadwyżkowych stóp zwrotu?

3. Czy fundusze należące do najlepszych pod względem niektórych charakterystyk rozkładu były jednocześnie jednymi z najgorszych pod względem innych charakterystyk rozkładu?

4. Jakie były w przeszłości szanse uzyskania dodatniej nadwyżkowej stopy zwrotu z poszczególnych funduszy?

\section{Dane i metodologia}

Badania przeprowadzono dla trzech grup polskich funduszy inwestycyjnych otwartych (FIO): 19 funduszy stabilnego wzrostu, 12 funduszy zrównoważonych, 15 funduszy akcyjnych. Liczebność grup była ograniczona przyjętym okresem badawczym - do badania zostały zakwalifikowane wszystkie FIO udziałowe, które funkcjonowały w okresie 16 grudnia 2005 roku - 22 czerwca 2017 roku. Do przeprowadzenia badań wykorzystano notowania dzienne jednostek uczestnictwa (j.u.) poszczególnych funduszy w postaci szeregów czasowych z przyjętego okresu badawczego. Źródłem danych był portal stooq.pl. Do obliczania stopy wolnej od ryzyka wykorzystano szeregi czasowe średniego oprocentowania 3-miesięcznych depozytów bankowych dla gospodarstw domowych (dane miesięczne z NBP). W badaniu przyjęto dwa horyzonty inwestycyjne: 5-letni i 10-letni. Horyzont 5-letni inwestycyjny został wybrany na podstawie rekomendacji dla inwestorów dotyczących minimalnego horyzontu inwestycyjnego na rynku akcji. Horyzont 10-letni wyniknął z zamiaru przeprowadzenia badania dla stosunkowo długiego horyzontu inwestycyjnego?

8 Za zabezpieczenie przed ryzykiem niedotrzymania warunków umowy można uznać gwarancje BFG (aktualnie do 100 tys. euro w danym banku). Depozyty bankowe nie są wolne od ryzyka stopy procentowej oraz ryzyka inflacji.

9 Badanie wyników polskich FIO w dłuższych horyzontach inwestycyjnych jest ograniczone stosunkowo krótkim funkcjonowaniem FIO w Polsce. Zob. wnioski na końcu artykułu. 
Badaniu poddano rozkłady empiryczne nadwyżkowych stóp zwrotu w okresie inwestycji (HPR - holding period return). Rozkłady uzyskano w następujący sposób. Najpierw sporządzono rozkłady empiryczne zwykłych HPR, stosując metodę symulacji historycznej - na podstawie notowań dziennych j.u. poszczególnych funduszy, wykorzystując ruchome okno obserwacji, obliczono wielokrotnie zwykłe HPR dla 5-letniego oraz 10-letniego horyzontu inwestycyjnego (długość okna obserwacji była równa najpierw 5-letniemu, a następnie 10-letniemu horyzontowi inwestycyjnemu). Okno obserwacji przesuwano każdorazowo o jeden dzień. W ten sposób uzyskano empiryczne rozkłady zwykłych stóp zwrotu z poszczególnych funduszy dla obu horyzontów inwestycyjnych. Następnie przyjmując założenie odnawiania się kwartalnego depozytu bankowego po oprocentowaniu dostępnym na dany moment i stosując tę samą metodę (ruchomego okna obserwacji), skonstruowano dwa rozkłady depozytowej stopy zwrotu w okresie inwestycji: dla 5-letniego i 10-letniego horyzontu inwestycyjnego. Rozkłady nadwyżkowych stóp zwrotu dla poszczególnych funduszy otrzymano, odejmując od każdej empirycznej zwykłej stopy zwrotu $\mathrm{z}$ danego funduszu depozytową stopę zwrotu właściwą dla danego momentu rozpoczęcia i zakończenia inwestycji.

Każdy rozkład nadwyżkowych HPR dla 5-letniego horyzontu inwestycyjnego wyznaczono na podstawie 1622 obserwacji. Hipotetyczny okres nabywania j.u. (lub zakładania depozytów) przez inwestora w przypadku horyzontu 5-letniego obejmował podokres badawczy: 16 grudnia 2005 roku - 22 czerwca 2012 roku, a hipotetyczny okres umarzania (odsprzedaży) j.u. przez inwestora - podokres: 16 grudnia 2010 roku - 22 czerwca 2017 roku. Każdy rozkład nadwyżkowych HPR dla 10-letniego horyzontu inwestycyjnego wyznaczono na podstawie 376 obserwacji. Hipotetyczny okres nabywania j.u. (lub zakładania depozytów) przez inwestora w przypadku horyzontu 10-letniego obejmował podokres badawczy: 16 grudnia 2005 roku 22 czerwca 2007 roku, a hipotetyczny okres umarzania (odsprzedaży) j.u. przez inwestora - podokres: 16 grudnia 2015 roku - 22 czerwca 2017 roku.

W celu uzyskania odpowiedzi na postawione pytania badawcze: 1) wyznaczono charakterystyki rozkładu: wartości najniższe (MIN), 10. percentyle (D1), kwartyle pierwsze (Q1), kwartyle drugie (Q2), średnie (ŚR), kwartyle trzecie (Q3), 90. percentyle (D9), wartości najwyższe (MAX); 2) obliczono miary zróżnicowania stóp zwrotu oraz charakterystyk rozkładu [rozstęp, względne odchylenie standardowe $(\mathrm{RSD})^{10}$, różnicę między wartością najniższą a średnią oraz różnicę między warto-

10 Względne odchylenia standardowego (RSD - relative standard deviation) jest wartością bezwzględną współczynnika zmienności. 
ścią najwyższą a średnią]; 3) obliczono szanse uzyskania w przeszłości dodatniej nadwyżkowej stopy zwrotu.

\section{Wyniki}

Aby odpowiedzieć na pierwsze pytanie badawcze, obliczono miary zróżnicowania nadwyżkowych HPR z poszczególnych funduszy dla obu horyzontów inwestycyjnych. Wyniki zaprezentowano w formie zbiorczej (w postaci przedziałów) w tabeli 1 .

Tabela 1. Miary zróżnicowania nadwyżkowych HPR

\begin{tabular}{|c|c|c|}
\hline Miary zróżnicowania & hi $=5$ lat & $\mathrm{hi}=10$ lat \\
\hline \multicolumn{3}{|c|}{ Fundusze stabilnego wzrostu } \\
\hline Rozstęp (p.p.) & $40-82$ & $8-28$ \\
\hline | średnia - min | (p.p.) & $17-38$ & $4-16$ \\
\hline | max - średnia $\mid$ (p.p.) & $19-42$ & $4-13$ \\
\hline $\operatorname{RSD}(\%)$ & $43-27878$ & $3-50$ \\
\hline \multicolumn{3}{|c|}{ Fundusze zrównoważone } \\
\hline Rozstęp (p.p.) & $81-137$ & $8-38$ \\
\hline | średnia - min | (p.p.) & $33-58$ & $4-14$ \\
\hline $\mid$ max - średnia | (p.p.) & $40-78$ & $4-24$ \\
\hline $\operatorname{RSD}(\%)$ & $47-3253$ & $4-39$ \\
\hline \multicolumn{3}{|c|}{ Fundusze akcyjne } \\
\hline Rozstęp (p.p.) & $118-198$ & $12-64$ \\
\hline | średnia - min | (p.p.) & $34-67$ & $5-26$ \\
\hline | max - średnia | (p.p.) & $79-131$ & $7-35$ \\
\hline RSD (\%) & $51-1144$ & $2-43$ \\
\hline
\end{tabular}

Źródło: obliczenia własne.

Przyjmując rozstęp za kryterium zróżnicowania, należy stwierdzić znaczące z punktu widzenia inwestora zróżnicowanie HPR z poszczególnych funduszy dla hi $=5$ lat. Zgodnie z oczekiwaniami najniższe zróżnicowanie cechowało HPR z funduszy stabilnego wzrostu, a najwyższe - z funduszy akcyjnych. Różnice między wartościami minimalnymi HPR a średnimi oraz maksymalnymi HPR a średnimi również wskazują na istotne z punktu widzenia inwestora zróżnicowanie HPR z poszczególnych funduszy dla hi = 5 lat. Także wartości RSD wskazują na dużą, a nawet skrajnie dużą zmienność HPR dla hi = 5 lat. W przypadku 10-letniego horyzontu inwestycyjnego zastosowane miary wskazują na różny stopień zróżnicowania HPR - od bardzo niskiego do dużego. 
Aby odpowiedzieć na drugie pytanie badawcze, obliczono miary zróżnicowania charakterystyk rozkładów nadwyżkowych HPR (tab. 2-4).

W grupie funduszy stabilnego wzrostu dla każdej z charakterystyk rozkładu rozstęp przekraczał 30 p.p. w przypadku 5-letniego horyzontu inwestycyjnego (tab. 2). Takie różnice można uznać za znaczące dla inwestora. Na znaczące dla inwestora zróżnicowanie wartości poszczególnych charakterystyk rozkładów wskazują także pozostałe miary: względne odchylenie standardowe (najniższe wartości dla MIN i D1), różnica między wartością najniższą a średnią (21-22 p.p. dla każdej z badanych charakterystyk) oraz różnica między wartością najwyższą a średnią (13-24 p.p.). W przypadku 10-letniego horyzontu inwestycyjnego poszczególne fundusze stabilnego wzrostu różniły się jeszcze bardziej pod względem wartości poszczególnych charakterystyk rozkładów HPR.

Tabela 2. Zróżnicowanie poszczególnych charakterystyk rozkładów HPR z funduszy stabilnego wzrostu

\begin{tabular}{|c|c|c|c|c|c|c|c|c|}
\hline \multirow{2}{*}{ Miary zróżnicowania } & \multicolumn{8}{|c|}{ Charakterystyki rozkładów nadwyżkowych stóp zwrotu } \\
\hline & MIN & D1 & Q1 & Q2 & ŚR & Q3 & D9 & MAX \\
\hline \multicolumn{9}{|c|}{ 5-letni horyzont inwestycyjny } \\
\hline Min. lokalne (p.p.) & -59 & -50 & -40 & -29 & -30 & -21 & -14 & 0 \\
\hline Max. lokalne (p.p.) & -23 & -15 & -5 & 5 & 4 & 15 & 25 & 45 \\
\hline Rozstęp (p.p.) & 36 & 35 & 35 & 34 & 34 & 36 & 39 & 45 \\
\hline Średnia (p.p.) & -37 & -29 & -19 & -8 & -10 & -1 & 7 & 22 \\
\hline $\mid$ min-średnia|(p.p.) & 21 & 22 & 21 & 21 & 21 & 21 & 21 & 22 \\
\hline max - średnia|(p.p.) & 15 & 13 & 14 & 13 & 13 & 15 & 18 & 24 \\
\hline RSD (\%) & 24 & 31 & 47 & 106 & 90 & 1822 & 138 & 61 \\
\hline \multicolumn{9}{|c|}{ 10-letni horyzont inwestycyjny } \\
\hline Min. lokalne (p.p.) & -67 & -66 & -65 & -64 & -64 & -63 & -62 & -60 \\
\hline Max. lokalne (p.p.) & -12 & -9 & -7 & -3 & -4 & 1 & 2 & 10 \\
\hline Rozstęp (p.p.) & 56 & 57 & 58 & 61 & 59 & 63 & 64 & 70 \\
\hline Średnia (p.p.) & -35 & -32 & -30 & -26 & -27 & -23 & -22 & -18 \\
\hline $\mid$ min - średnia|(p.p.) & 32 & 34 & 35 & 38 & 37 & 39 & 40 & 42 \\
\hline $\mid$ max - średnia|(p.p.) & 24 & 24 & 23 & 23 & 22 & 24 & 24 & 28 \\
\hline RSD (\%) & 43 & 49 & 53 & 65 & 62 & 72 & 79 & 99 \\
\hline
\end{tabular}

Źródło: obliczenia własne.

Analizując fundusze zrównoważone, stwierdzono, iż poszczególne fundusze zrównoważone, podobnie jak fundusze stabilnego wzrostu, różniły się znacząco pod względem wartości średnich, MIN, MAX i kwantyli rozkładów nadwyżkowych stóp zwrotu (tab. 3). Dla 5-letniego horyzontu inwestycyjnego rozstęp przyjmował wartości od 37 p.p. (dla MIN) do 69 p.p. (dla MAX). Różnice między wartością minimalną 
a średnią wynosiły od 21 p.p. do 31 p.p. Względne odchylenie standardowe wskazało na niskie zróżnicowanie MIN i D1, ale duże lub bardzo duże pozostałych charakterystyk rozkładu. W przypadku 10-letniego horyzontu inwestycyjnego poszczególne fundusze zrównoważone różniły się jeszcze bardziej pod względem wartości charakterystyk rozkładów stóp zwrotu.

Tabela 3. Zróżnicowanie poszczególnych charakterystyk rozkładów HPR z funduszy zrównoważonych

\begin{tabular}{|c|c|c|c|c|c|c|c|c|}
\hline \multirow{2}{*}{ Miary zróżnicowania } & \multicolumn{8}{|c|}{ Charakterystyki rozkładów nadwyżkowych stóp zwrotu } \\
\hline & MIN & D1 & Q1 & Q2 & ŚR & Q3 & D9 & MAX \\
\hline \multicolumn{9}{|c|}{ 5-letni horyzont inwestycyjny } \\
\hline Min. lokalne (p.p.) & -79 & -71 & -60 & -44 & -43 & -29 & -14 & 8 \\
\hline Max. lokalne (p.p.) & -42 & -29 & -15 & 6 & -1 & 24 & 45 & 77 \\
\hline Rozstęp (p.p.) & 37 & 42 & 45 & 50 & 42 & 54 & 58 & 69 \\
\hline Średnia (p.p.) & -58 & -46 & -32 & -14 & -16 & -1 & 13 & 39 \\
\hline $\mid$ min - średnia $\mid$ (p.p.) & 21 & 24 & 28 & 29 & 27 & 29 & 27 & 31 \\
\hline $\mid \max$ - średnia $\mid$ (p.p.) & 15 & 18 & 17 & 20 & 15 & 25 & 31 & 38 \\
\hline RSD (\%) & 16 & 22 & 38 & 95 & 78 & 1880 & 115 & 52 \\
\hline \multicolumn{9}{|c|}{ 10-letni horyzont inwestycyjny } \\
\hline Min. lokalne (p.p.) & -90 & -89 & -88 & -87 & -87 & -85 & -84 & -82 \\
\hline Max. lokalne (p.p.) & -21 & -18 & -16 & -14 & -14 & -12 & -9 & 1 \\
\hline Rozstęp (p.p.) & 69 & 70 & 71 & 72 & 73 & 74 & 75 & 83 \\
\hline Średnia (p.p.) & -52 & -49 & -47 & -43 & -43 & -40 & -38 & -31 \\
\hline $\mid$ min -średnia $\mid$ (p.p.) & 38 & 40 & 41 & 43 & 43 & 45 & 47 & 51 \\
\hline $\mid$ max - średnia $\mid$ (p.p.) & 30 & 31 & 30 & 29 & 29 & 29 & 28 & 32 \\
\hline RSD (\%) & 37 & 41 & 44 & 50 & 49 & 55 & 60 & 79 \\
\hline
\end{tabular}

Źródło: obliczenia własne.

Analizując grupę funduszy akcyjnych, stwierdzono, iż poszczególne fundusze różniły się znacznie pod względem wartości średnich, MIN, MAX i kwantyli rozkładów nadwyżkowych stóp zwrotu (tab. 4). Podobnie jak w przypadku funduszy stabilnego wzrostu i funduszy zrównoważonych, najmniejsze zróżnicowanie cechowało wartości minimalne rozkładu, a największe - wartości maksymalne. Rozstęp przyjmował wartości od 36 p.p. do 102 p.p. dla hi $=5$ lat oraz od 60 p.p. do 100 p.p. dla hi $=10$ lat. Różnice między wartością najniższą a średnią wynosiły od 21 p.p. do 43 p.p. dla hi $=5$ lat oraz od 32 p.p. do 53 p.p. dla hi $=10$ lat. Różnice między wartością najwyższą a średnią wynosiły od 15 do 60 p.p. dla hi $=5$ lat oraz od 28 p.p. do 47 p.p. dla hi $=10$ lat. 
Tabela 4. Zróżnicowanie poszczególnych charakterystyk rozkładów HPR z funduszy akcyjnych

\begin{tabular}{|c|c|c|c|c|c|c|c|c|}
\hline \multirow{2}{*}{ Miary zróżnicowania } & \multicolumn{8}{|c|}{ Charakterystyki rozkładów nadwyżkowych stóp zwrotu } \\
\hline & MIN & D1 & Q1 & Q2 & ŚR & Q3 & D9 & MAX \\
\hline \multicolumn{9}{|c|}{ 5-letni horyzont inwestycyjny } \\
\hline Min. lokalne (p.p.) & -99 & -89 & -77 & -54 & -54 & -38 & -14 & 25 \\
\hline Max. lokalne (p.p.) & -63 & -44 & -27 & -3 & -3 & 16 & 48 & 127 \\
\hline Rozstęp (p.p.) & 36 & 45 & 50 & 51 & 50 & 54 & 62 & 102 \\
\hline Średnia (p.p.) & -78 & -63 & -47 & -24 & -24 & -7 & 16 & 68 \\
\hline $\mid$ min - średnia|(p.p.) & 21 & 26 & 31 & 30 & 30 & 31 & 30 & 43 \\
\hline $\mid \max$-średnia|(p.p.) & 15 & 19 & 19 & 21 & 20 & 23 & 32 & 60 \\
\hline $\mathrm{RSD}(\%)$ & 12 & 18 & 26 & 54 & 52 & 194 & 104 & 34 \\
\hline \multicolumn{9}{|c|}{ 10-letni horyzont inwestycyjny } \\
\hline Min. lokalne (p.p.) & -112 & -109 & -108 & -106 & -106 & -105 & -103 & -100 \\
\hline Max. lokalne (p.p.) & -51 & -43 & -39 & -34 & -34 & -21 & -14 & 0 \\
\hline Rozstęp (p.p.) & 60 & 66 & 69 & 73 & 73 & 83 & 88 & 100 \\
\hline Średnia (p.p.) & -79 & -74 & -70 & -66 & -65 & -61 & -56 & -47 \\
\hline $\mid$ min - średnia|(p.p.) & 32 & 35 & 38 & 41 & 41 & 44 & 47 & 53 \\
\hline $\mid \max$-średnia|(p.p.) & 28 & 31 & 31 & 32 & 32 & 39 & 42 & 47 \\
\hline RSD (\%) & 19 & 23 & 25 & 30 & 30 & 35 & 40 & 53 \\
\hline
\end{tabular}

Źródło: obliczenia własne.

Aby odpowiedzieć na trzecie pytanie badawcze, w każdej z badanych grup funduszy wskazano trzy fundusze najlepsze i trzy fundusze najgorsze pod względem poszczególnych charakterystyk rozkładu. Tylko jeden fundusz (Allianz Akcji) był jednym z najlepszych pod względem niektórych charakterystyk (MIN, $10 \%$ ), a jednocześnie jednym z najgorszych pod względem innych charakterystyk (Q3, 90\%, MAX). W przypadku pozostałych funduszy nie stwierdzono takiej zależności. Przeciwnie, wyodrębniono fundusze będące jednymi z najlepszych w swojej grupie pod względem wszystkich badanych charakterystyk ${ }^{11}$ (KBC Stabilny, UniKorona Zrównoważony, Credit Agricole Dynamiczny Polski, UniKorona Akcje, Legg Mason Akcji) oraz fundusze będące jednymi z najgorszych pod względem wszystkich badanych charakterystyk ${ }^{12}$ (Allianz Stabilnego Wzrostu, Pioneer Stabilnego Wzrostu, Novo Zrównoważonego Wzrostu, Pioneer Zrównoważony, Pioneer Akcji Polskich).

Ostatnie pytanie badawcze dotyczyło szansy uzyskania dodatniej nadwyżkowej stopy zwrotu w przeszłości. Na podstawie sporządzonych rozkładów nadwyżkowych

\footnotetext{
11 Tzw. hot hands.

12 Tzw. icy hands.
} 
stóp zwrotu dla każdego funduszu obliczono szanse (rys. 1-3). Różniły się one diametralnie w zależności od horyzontu inwestycyjnego.

Rysunek 1. Szanse uzyskania dodatniej nadwyżkowej HPR - fundusze stabilnego wzrostu

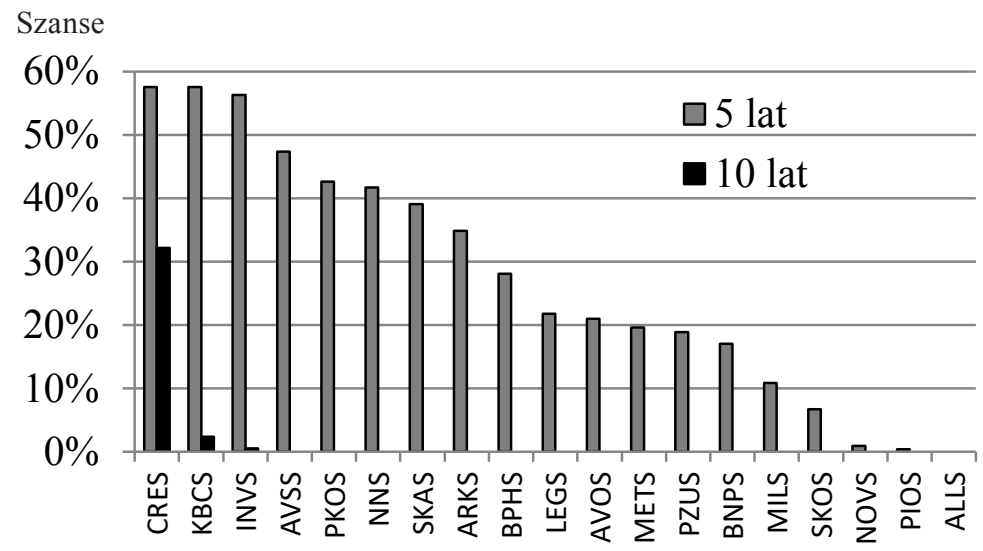

Źródło: opracowanie własne.

Rysunek 2. Szanse uzyskania dodatniej nadwyżkowej HPR - fundusze zrównoważone

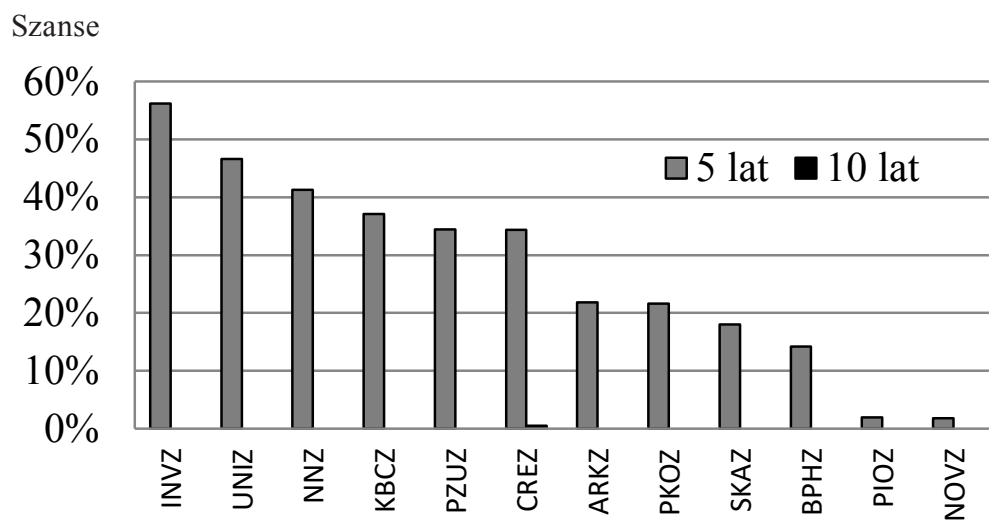

Źródło: opracowanie własne. 
Rysunek 3. Szanse uzyskania dodatniej nadwyżkowej HPR - fundusze akcyjne

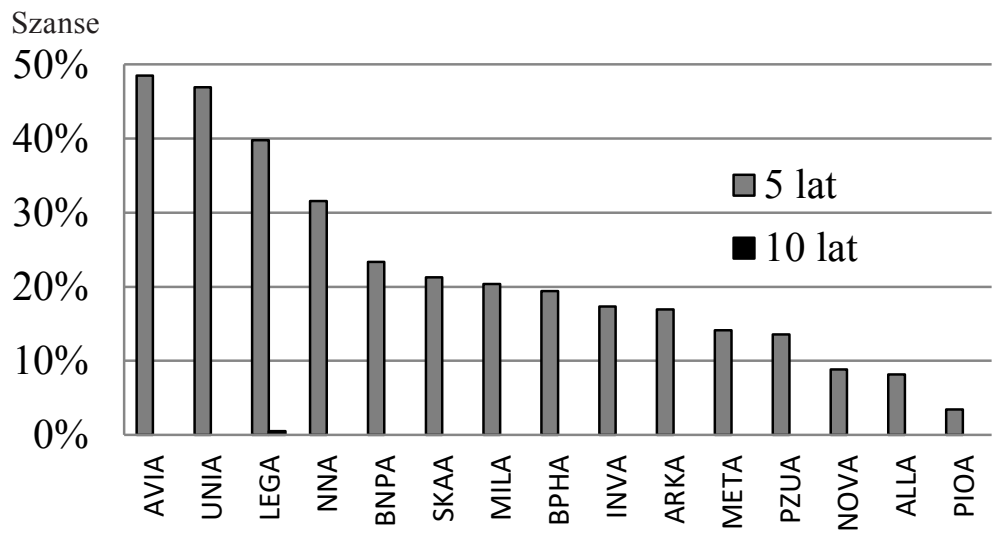

W przypadku funduszy stabilnego wzrostu i 5-letniego horyzontu inwestycyjnego tylko dwa fundusze cechowała zerowa szansa na dodatnią nadwyżkową stopę zwrotu; szansa dla pozostałych 17 funduszy wahała się od 1\% do 58\% - jednak tylko dla trzech funduszy przekroczyła 50\%. W przypadku tej samej grupy funduszy i 10-letniego horyzontu inwestycyjnego wyjątkowo wysoką szansą na dodatnią nadwyżkową stopę zwrotu cechował się fundusz Credit Agricole Stabilnego Wzrostu (32\%). Pozostałe fundusze charakteryzowała szansa zerowa lub bliska zeru. W grupie funduszy zrównoważonych dla 5-letniego horyzontu inwestycyjnego szanse uzyskania dodatniej nadwyżkowej stopę zwrotu wynosiły od 2\% do 56\%; w przypadku większości funduszy szansa była niższa niż 50\%. Dla 10-letniego horyzontu jedynie jeden fundusz zrównoważony cechowała niewielka $(0,5 \%)$ szansa na dodatnią nadwyżkową stopę zwrotu. W grupie funduszy akcyjnych dla 5-letniego horyzontu inwestycyjnego szanse uzyskania dodatniej nadwyżkowej stopę zwrotu wynosiły od $3 \%$ do 49\%. Dla 10-letniego horyzontu jedynie jeden fundusz cechowała niewielka $(0,5 \%)$ szansa na dodatnią nadwyżkową stopę zwrotu. 


\section{Podsumowanie}

Przeprowadzone badanie pozwoliło na sformułowanie następujących wniosków.

Mediany i wartości oczekiwane (średnie) rozkładów nadwyżkowych stóp zwrotu uznane zostały za charakterystyki szczególnie ważne, mogące służyć wyznaczeniu przeciętnej premii za ryzyko dla danego funduszu i zadanego horyzontu inwestycyjnego. Ich wartości najczęściej wskazywały na ujemną przeciętną premię za ryzyko. Dla 5-letniego horyzontu inwestycyjnego dodatnie wartości mediany pojawiły się w przypadku trzech funduszy stabilnego wzrostu i jednego funduszu zrównoważonego. Dla 10-letniego horyzontu inwestycyjnego wszystkie mediany miały wartości ujemne. Dla 5-letniego horyzontu inwestycyjnego dodatnie wartości średniej pojawiły się w przypadku dwóch funduszy stabilnego wzrostu; dla 10-letniego horyzontu inwestycyjnego wszystkie średnie były ujemne. Zatem tylko inwestor mający skłonność do ryzyka powinien być zainteresowany inwestowaniem w fundusze. Ponadto występujące w przypadku każdego funduszu duże lub skrajnie duże zróżnicowanie nadwyżkowych stóp zwrotu (dla hi $=5$ lat) nasuwa wątpliwości co do zasadności wykorzystania w praktyce średniej premii za ryzyko dla danego funduszu.

Występujące znaczące zróżnicowanie poszczególnych charakterystyk rozkładów stóp zwrotu w badanych grupach powoduje pojawienie się wątpliwości co do zasadności szacowania premii za ryzyko jako średniej wartości dla całej grupy funduszy. W każdej z badanych grup funduszy można było zidentyfikować wyraźnie lepsze i wyraźnie gorsze fundusze pod względem charakterystyk rozkładów.

Stwierdzono, iż inwestor nie musi wybierać między funduszami o najmniejszym ryzyku w danej grupie a funduszami dającymi szansę na najwyższe nadwyżkowe stopy zwrotu (tzn. fundusze o najwyższych wartościach: MIN, D1, Q1 nie cechowały się jednocześnie najniższymi wartościami: Q3, D9, MAX). W każdej $\mathrm{z}$ badanych grup funduszy udziałowych wskazano fundusz należący do najlepszych pod względem wszystkich charakterystyk.

Szanse na uzyskanie w przeszłości premii za ryzyko należy uznać moim zdaniem za niezbyt wysokie przy założeniu 5-letniego horyzontu inwestycyjnego nawet w przypadku funduszy stabilnego wzrostu. Ponadto stwierdzono duże zróżnicowanie funduszy pod tym kątem w każdej z badanych grup. Natomiast przy założeniu 10-letniego horyzontu inwestycyjnego prawie każdy fundusz cechowała zerowa lub praktycznie zerowa szansa na zrealizowanie premii za ryzyko. 
O ile szanse na uzyskanie w przeszłości premii za ryzyko nie były zbyt duże, o tyle wysokość hipotetycznie uzyskanej premii przy założeniu 5-letniego horyzontu inwestycyjnego przedstawiała się atrakcyjnie. Wartości Q3 w przypadku dwóch funduszy stabilnego wzrostu, dwóch funduszy zrównoważonych i dwóch funduszy akcyjnych przekroczyły $10 \%$. Wartości 90 . Percentyli w przypadku ośmiu funduszy stabilnego wzrostu przekroczyły 10\% (w tym dla dwóch funduszy wyniosły ok. 25\%); w przypadku siedmiu funduszy zrównoważonych przekroczyły one $13 \%$ (w tym jeden fundusz osiągnął wartość 45\%); w przypadku dziesięciu funduszy akcyjnych przekroczyły $11 \%$ (w tym cztery fundusze osiągnęły wartość powyżej $30 \%$ ). Wartości najwyższe rozkładów w grupie funduszy stabilnego wzrostu należały do przedziału 0-45\%; w grupie funduszy zrównoważonych - od 9\% do 77\%; w grupie funduszy akcyjnych - od 49\% do $127 \%$. Jednak dla dłuższego, to jest 10 -letniego horyzontu inwestycyjnego najwyższe wartości rozkładów nadwyżkowych stóp zwrotu w przypadku prawie każdego funduszu były ujemne lub bliskie zeru. Wyjątek stanowił Credit Agricole Stabilnego Wzrostu (MAX $=10 \%$ ). Praktycznie całkowicie ujemne rozkłady nadwyżkowych stóp zwrotu stanowią interesujący wynik, mając na uwadze rekomendacje długich horyzontów inwestycyjnych na rynku akcji. Wskazują bowiem na nieopłacalność 10-letniego inwestowania w badanym okresie w udziałowe FIO w porównaniu z oszczędzaniem na depozytach bankowych.

Podsumowując, należy zwrócić uwagę na problem prowadzenia badań dotyczących efektywności funduszy inwestycyjnych na rynku polskim w długich horyzontach inwestycyjnych. Problem ten wynika ze stosunkowo krótkiego okresu funkcjonowania funduszy inwestycyjnych w Polsce. Wydłużanie horyzontu inwestycyjnego powoduje zmniejszenie liczebności grupy badawczej ze względu na daty rozpoczęcia działalności poszczególnych FIO. Przeprowadzone w niniejszym artykule badania dla 10-letniego horyzontu inwestycyjnego oparto na stosunkowo krótkim okresie nabywania i sprzedaży j.u. ${ }^{13}$ Jest to oczywiście zbyt krótki okres badawczy, aby sformułować ogólne wnioski. Duży wpływ na kształtowanie się nadwyżkowych stóp zwrotu w badanym okresie miało stosunkowo wysokie oprocentowanie depozytów (od 1,6\% do7,3\%; średnie 3,8\%) przyjęte w przeprowadzonym badaniu jako stopa wolna od ryzyka. Można zatem wyrazić przypuszczenie, że obserwowana od pewnego czasu tendencja malejąca oprocentowania depozytów bankowych w Polsce może spowodować bardziej atrakcyjne kształtowanie się premii za ryzyko w przyszłości - większe szanse jej uzyskania i wyższe jej wartości. Otrzymane w prze-

13 Szczegóły zostały opisane w części „Dane i metodologia”. 
prowadzonych badaniu wyniki nie powinny zatem stanowić jedynej podstawy do szacowania oczekiwanej premii za ryzyko inwestowania $\mathrm{w}$ fundusze udziałowe ${ }^{14}$.

\section{Literatura}

Aspadarec, W., Majewski S. (2016). Persystencja stóp zwrotu quasi-funduszy hedge na polskim rynku kapitałowym. Annales Universitatis Mariae Curie-Skłodowska LublinPolonia, L (4), 11-23. DOI: 10.17951/h.2016.50.4.11.

Byrka-Kita, K. (2006). Dylematy szacowania stopy zwrotu wolnej od ryzyka - praktyka a teoria. W: J. Duraj (red.), Wartość przedsiębiorstwa - z teorii i praktyki zarządzania (s. 95-110). Łódź: Wyd. Naukowe NOVUM.

Byrka-Kita, K. (2013). Premia z tytułu ryzyka - przegląd technik. Studia i Prace Wydziału Nauk Ekonomicznych i Zarzadzania, 34 (1), 37-52.

Czekaj, J., Grotowski, M. (2014). Krótkoterminowa persystencja wyników osiąganych przez fundusze akcyjne działające na polskim rynku kapitałowym. Ekonomista, 4, 545-557.

Damodaran, A. (2011). Equity Risk Premiums (ERP): Determinants, Estimation and Implications - The 2011 Edition.

Dawidowicz, D. (2012). Efektywność nowych funduszy inwestycyjnych - analiza porównawcza. W: J. Harasim, J. Cichy (red.), Finanse w niestabilnym otoczeniu - dylematy $i$ wyzwania. Rynki finansowe (s. 369-379). Katowice: Wyd. UE w Katowicach.

Dawidowicz, D. (2013). Ocena efektywności nowych i pozostałych funduszy inwestycyjnych akcji polskich w latach 2000-2012. Research Papers of the Wroclaw University of Economics/Prace Naukowe Uniwersytetu Ekonomicznego we Wrocławiu, 323, $53-65$.

Dittmann, I. (2016a). A Comparative Analysis of the Rates of Return on Open-End Debt Investment Funds in Poland in the Years 2005-2015. Transformations in Business \& Economics, 15, 2A (38A), 354-372.

Dittmann, I. (2016b). Open-end Debt Investment Funds and Bank Deposits in Poland 1995 2015. A Comparison of the a Posteriori Probability (Chance) of Failure to Achieve the Level of Aspiration. Ekonometria, 2 (52), 77-97. DOI:10.15611/ekt.2016.2.06.

Dittmann, I. (2016c). Zróżnicowanie gotówkowych i pieniężnych funduszy inwestycyjnych otwartych w Polsce w latach 2005-2015 pod względem stóp zwrotu. Prace Naukowe Uniwersytetu Ekonomicznego we Wrocławiu, 462, 11-32,

Fernández, P. (2004). Market Risk Premium: Required, Historical and Expected. International Center for Financial Research Working Paper, 574, Barcelona: University of Navarra.

14 Na problem szacowania oczekiwanej premii za ryzyko na podstawie historycznej premii za ryzyko na rynkach wschodzących zwraca uwagę Damoradan (2011). 
Jamróz, P. (2013) Efektywność wybranych FIO rynku akcji w latach 2003-2011. Zeszyty Naukowe Uniwersytetu Szczecińskiego, 768, Finanse, Rynki Finansowe, Ubezpieczenia, 63, 193-206.

Julliard, Ch., Ghosh, A. (2012). Can Rare Events Explain the Equity Premium Puzzle? The Review of Financial Studies, 25 (10), 3037-3076. https://doi.org/10.1093/rfs/hhs078.

Jurek-Wasilewska, K. (2014). Efektywność inwestowania w otwartych funduszach inwestycyjnych w Polsce w latach 2001-2010. Finanse i Prawo Finansowe, 1, 20-33.

Karkowska, R., Niewińska, K. (2013). Analiza zmienności stóp zwrotu funduszy inwestycyjnych w Polsce. Zarzadzanie i Finanse. Prace i Materiały Wydziału Zarzadzania Uniwersytetu Gdańskiego, 11 (1/1), 255-267.

Karpio, A., Żebrowska-Suchodolska, D. (2013). Porównanie efektywności inwestycyjnej FIO z wykorzystaniem information ratio i wskaźnika Sortino. Zeszyty Naukowe Uniwersytetu Szczecińskiego, 768, Finanse, Rynki Finansowe, Ubezpieczenia, 63, 221-232.

Kompa, K., Witkowska, D. (2010). Porównanie efektywności wybranych otwartych funduszy inwestycyjnych w okresie hossy i bessy. Acta Scientiarum Polonorum Oeconomia, 9 (3), 169-180.

Kurek, B. (2009). Premia za ryzyko na rynku kapitałowym - kontrowersje metrologiczne. Master of Business Administration, 17 (6), 33-41.

Kurek, B. (2011). Hipoteza deterministycznej premii za ryzyko. Kraków: Wyd. UE w Krakowie.

Mehra, R. (2003). The Equity Premium: Why Is It a Puzzle? (corrected). Financial Analysts Journal, 59 (1), $54-69$.

Mehra, R. (2011). The Equity Premium Puzzle Revisited. Research Foundation Publications, December, 148-154

Mentel, G., Brozyna, J., Szetela, B., Kompa, K. (2016). Macro and Microeconomic Factors of Investment Efficiency of Open Investment Funds in the Period of 1997-2015. Transformations in Business \& Economics, 15, 3 (39), 122-140.

Mentel, G., Horváthová, Z. (2016). Factors of Efficiency of Open Investment Funds in 19972015. Economics and Sociology, 9 (1), 101-113. DOI: 10.14254/2071-789X.2016/9-1/7.

Mentel, G., Szetela, B., Tvaronavičienè, M. (2016). Qualifications of Managers vs. Effectiveness of Investment Funds in Poland. Economics and Sociology, 9 (2), 126-136. DOI: 10.14254/2071-789X.2016/9-2/8.

Miziołek, T. (2007). Proces integracji rynku funduszy inwestycyjnych w Polsce z rynkiem europejskim. W: W. Dębski, W. Włodarczyk-Guzek (red.), Wybrane zagadnienia z zakresu finansów i handlu międzynarodowego (s. 165-187). Łódź: Wyd. UŁ.

Miziołek, T. (2014). Ocena efektywności zarządzania funduszami ETF posiadającymi ekspozycję na polski rynek akcji. W: K. Jajuga, W. Ronka-Chmielowiec (red.), Inwestycje finansowe i ubezpieczenia - tendencje światowe a rynek polski (s. 224-235). Wrocław: Wyd. UE we Wrocławiu.

Miziołek, T. (2015). Wskaźnik active share na rynku akcyjnych funduszy inwestycyjnych w Polsce. Zeszyty Naukowe Uniwersytetu Szczecińskiego, 862, Finanse, Rynki Finansowe, Ubezpieczenia, 75, 343-354. 
Miziołek, T., Trzebiński, A. (2017). Efektywność polskich funduszy inwestycyjnych - przegląd metod i literatury. Finanse. Czasopismo Komitetu Nauk o Finansach PAN, 10 (1), 93-119.

Olbryś, J. (2009). Relative Risk Measures of Polish Equity Open-end Mutual Funds' Portfolios in a Bear Market Period. Optimum. Studia Ekonomiczne, 3 (43), 134-151.

Olbryś, J. (2011). Comparative Analysis of Polish Equity Open-end Mutual Funds' Portfolios Using Estimators of Risk Measures and Risk-Tolerance Coefficient. W: W. Milo, G. Szafrański, P. Wdowiński (red.), Financial Markets. Principles of Modelling, Forecasting and Decision-Making, Find Econ Monograph Series: Advances in Financial Market Analysis (s. 141-154). Vol. 9. Lodz: University Press.

Pietrzyk, R. (2013). Efektywność inwestycji polskich funduszy inwestycyjnych z tytułu doboru papierów wartościowych i umiejętności wykorzystania trendów rynkowych. Prace Naukowe Uniwersytetu Ekonomicznego we Wrocławiu, 278, 351-361.

Pietrzyk, R. (2014a). Evaluation of Mutual Fund Performance on Polish Capital Market with the Use of Market Timing Models. W: J. Talasova, J. Stoklasa, T. Talasek (red.), 32nd International Conference Mathematical Methods in Economics. Conference Proceedings (s. 789-794). Palacky University.

Pietrzyk, R. (2014b). Ocena efektywności inwestycji gospodarstw domowych na przykładzie funduszy inwestycyjnych. Annales Universitatis Mariae Curie-Skłodowska. Sectio H, Oeconomia, 48/3, 263-274.

Perez, K. (2011a). Analyzing Short-term Persistence in Polish Mutual Funds Performance. Advances in Global Management Development, XX, 157-164.

Perez, K. (2011b). Persistence in Polish Mutual Fund Performance before and during the Financial Crisis. W: Euroconference 2011: Crisis and Recovery in Emerging Markets, Society for the Study of Emerging Markets (s. 155). Izmir 2011. Materiały konferencyjne.

Perez, K. (2011c). Rozwój rynku funduszy inwestycyjnych po wstąpieniu do Unii Europejskiej. Zeszyty Naukowe Uniwersytetu Ekonomicznego w Poznaniu, 207, 184-202.

Perez, K. (2012a). Efektywność funduszy inwestycyjnych: podejście techniczne i fundamentalne. Warszawa: Difin.

Perez, K. (2012b). Persystencja stóp zwrotu polskich funduszy inwestycyjnych. Finanse, 1, $81-113$.

Perez, K. (2014). Polish Absolute Return Funds and Stock Funds. Short and Long Term Performance Comparison. Folia Oeconomica Stetinensia, 14 (2), 179-197.

Rutkowska-Ziarko, A., Garsztka P. (2016). Oceny efektywności zarządzania funduszami inwestycyjnymi przy wykorzystaniu kwantylowych miar ryzyka. Olsztyn Economic Journal, 11 (3), 277-298.

Trzebiński, A.A. (2013). Zmiany polskiego rynku funduszy inwestycyjnych w latach 19922011. Acta Universitatis Nicolai Copernici, Ekonomia, XLIV (2), 261-275. DOI: http:// dx.doi.org/ 10.12775/AUNC_ECON.2013.017. 
Trzebiński, A.A. (2016). Efekt przetrwania i premia za przetrwanie na przykładzie stóp zwrotu polskich funduszy inwestycyjnych otwartych. Ruch Prawniczy, Ekonomiczny i Socjologiczny, LXXVIII (3), 169-187.

Welch, I. (2000). Views of Financial Economists on the Equity Premium and on Professional Controversies. Journal of Business, 73 (4), 501-537.

Zamojska, A. (2012). Efektywność funduszy inwestycyjnych w Polsce: studium teoretyczno-empiryczne. Warszawa: C.H. Beck.

Zamojska, A. (2015). Zastosowanie analizy falkowej w ocenie efektywności funduszy inwestycyjnych. Prace Naukowe Uniwersytetu Ekonomicznego we Wrocławiu, 385, 325-333.

Żebrowska-Suchodolska, D. (2017). Zastosowanie wybranych miar zysków i strat do badania efektywnościinwestycyjnej funduszy akcyjnych w latach 2007-2015. Finanse, Rynki Finansowe, Ubezpieczenia, 2 (86), 263-272. DOI: 10.18276/frfu.2017.86-22.

\title{
DISTRIBUTIONS OF EXCESS RETURNS FROM INVESTMENT FUNDS - EVALUATION OF HISTORICAL PREMIUM FOR RISK
}

\begin{abstract}
The aim of the study was to analyze the development of excess returns from the Polish open-ended funds and the assessment of the risk premium from the perspective of the individual investor. The study was conducted for stable growth, sustainable and equity funds in 2005-2017. Two investment horizons were adopted: 5-year and 10-year. The characteristics of excess return distributions and the chances of obtaining a positive excess return were calculated. It was found, among others: 1) the large variation in excess returns gives rise to doubts as to the appropriateness of the risk premium estimation as the average value for a given fund and for the whole group of funds; 2) the chances of obtaining a positive risk premium in the past were very different for each fund; 3 ) for the 10-year investment horizon the risk premium was negative.
\end{abstract}

\section{Translated by Iwona Dittmann}

Keywords: investment funds, personal finance, excess returns, risk premium JEL Codes: D14, G11 